UDK 669:539.4

DOI: 10.30838/J.PMHTM.2413.230321.66.736

\title{
TRANSITION FROM ENGINEERING STRAIN TO THE TRUE STRAIN IN ANALYTICAL DESCRIPTION OF METALS HARDENING
}

\author{
DOLZHANSKYI A.M. ${ }^{1}$, Dr. Sc. (Tech.), Prof., \\ AYUPOVA T.A. $.^{*}, P h . D .$, Assoc. Prof., \\ NOSKO O.A. ${ }^{3}$, Ph. D., Assoc.Prof., \\ RYBKIN O.P. ${ }^{4}$, Student, \\ AYUPOV O.A. ${ }^{5}$, Student
}

${ }^{1}$ Department of Quality, Standardization and Certification, National Metallurgical Academy of Ukraine, Dnipro, 4, Haharina Ave.,
tel.+38 (056) 746-05-49, e-mail: a.dolzhanskiy@gmail.com, ORCID ID: 0000-0002-7552-3012
$2^{2 *}$ Department of Material Science by the name of Yu.M.Taran-Zhovnir, National Metallurgical Academy of Ukraine, Dnipro, 4,
Haharina Ave., tel. +38 (056) 374-89-36, e-mail: kaf.material@metal.nmetau.edu.ua, ORCID ID: 0000-0002-5706-4211
${ }^{3}$ Department of Material Science by the name of Yu.M.Taran-Zhovnir, National Metallurgical Academy of Ukraine, Dnipro, 4,
Haharina Ave., tel. +38 (056) 374-89-36, e-mail: kaf.material@metal.nmetau.edu.ua, ORCID ID: 0000-0002-5749-7578
${ }^{4}$ Department of Material Science by the name of Yu.M.Taran-Zhovnir, National Metallurgical Academy of Ukraine, Dnipro, 4,
Haharina Ave., tel. +38 (056) 374-89-36, e-mail: kaf.material@metal.nmetau.edu.ua
${ }^{5}$ Department of Quality, Standardization and Certification, National Metallurgical Academy of Ukraine, Dnipro, 4, Haharina Ave.,
tel. +38 (056) 746-05-49, e-mail: tk136@ua.fm, ORCID ID: 0000-0002-1414-0835

Abstract. Purpose of the work is related with the impossibility of correctly estimating the strain hardening of metals (alloys) in the area of their large total deformations due to absence of additivity in the traditionally used value of engineering strain $\gamma$, its nonlinear change in the area of large values, and absence of data in the technical literature HallPetch coefficient $\mathrm{Ai}$ for logarithmic true deformations, which led to the task of correct transition from the values of the engineering strain $0<\gamma<50 \ldots 60 \%$ to the value of the true logarithmic strainn $0<\varepsilon<1$...3. Methodology. The theoretical analysis of the regularities of deformation hardening of metals (alloys) from the engineering strain is carried out, the transition from engineering to logarithmic ("true") strain of metals (alloys) by analytical representation of metal hardening graphs as a function of logarithmic (true) strain. in contrast to the degree of engineering strain is presented. Originality. Analytical expressions are presented that allow the use of known theoretical data on the strain hardening of metals (alloys) at small $(50 \ldots 60 \%)$ total engineering strains $\gamma$ during cold pressure treatment to transition to logarithmic (true) strain $\varepsilon$ with large total deformations. Practical value. The obtained mathematical expressions allow to use the accumulated in the technical literature experimental data on the hardening of metals and alloys with small engineering strains in the processes of cold processing of metals (alloys) by pressure to determine the hardening with large total logarithmic (true) strains. These data can also be used to solve metallophysical problems of metal processing by pressure associated with large total compressions.

Keywords: cold forming of metals and alloys; hardening; degree of deformation

\section{ПЕРЕХІД ВІД УМОВНОЇ ДЕФОРМАЦІЇ ДО ЛОГАРИФМІЧНОЇ ПРИ АНАЛІТИЧНОМУ ОПИСУ ЗМЦЦЕННЯ МЕТАЛІВ}

ДОЛЖАНСЬКИЙ А. М. ${ }^{1}$, докт. техн. наук, проф., АЮПОВА Т. А..$^{*}$, канд. техн. наук, дои.,

НОСКО О. А. ${ }^{3}$, канд. техн. наук, дои.,

РИБКІН О. П. ${ }^{4}$, cmyд.,

АЮПОВ О. А., , cmyд.

\footnotetext{
${ }^{1}$ Кафедра якості, стандартизації та сертифікації, Національна металургійна академія України, пр. Гагаріна, 4, 49005, Дніпро, Україна, тел. +38 (056) 746-05-49, e-mail e-mail: a.dolzhanskiy@gmail.com, ORCID ID:0000-0002-7552-3012

Кафедра матеріалознавства ім. Ю. М. Тарана-Жовніра, Національна металургійна академія України, пр. Гагаріна, 4, 49005, Дніпро, Україна, тел. +38 (056) 374-89-36, e-mail:kaf.material@metal.nmetau.edu.ua, ORCID ID: 0000$0002-5706-4211$

3 Кафедра матеріалознавства ім. Ю. М. Тарана-Жовніра, Національна металургійна академія України, пр. Гагаріна, 4, 49005, Дніпро, Україна, тел. +38 (056) 374-82-66, e-mail:kaf.material@metal.nmetau.edu.ua, ORCID ID: 00000002-5749-7578
} 
${ }^{4}$ Кафедра матеріалознавства ім. Ю. М. Тарана-Жовніра, Національна металургійна академія України, пр. Гагаріна, 4, 49005, Дніпро, Україна, тел. +38 (056) 374-82-66, e-mail:kaf.material@metal.nmetau.edu.ua

${ }^{5}$ Кафедра якості, стандартизації та сертифікації, Національна металургійна академія України, пр. Гагаріна, 4, 49005, Дніпро, Україна, тел. +38 (056) 746-05-49, e-mail: tk136@ua.fm, ORCID ID: 0000-0002-1414-0835

Анотація. Мета роботи пов'язана з неможливістю коректної оцінки деформаційного зміцнення металів (сплавів) в області їх великих сумарних деформацій через відсутність адитивності у традиційно використованій величині відносного (умовного) ступеня деформації $\gamma$, а також з його нелінійною зміною в області великих значень та відсутністю в технічній літературі даних щодо коефіцієнта Холла-Петча $A i$ для істинних деформацій, що зумовило завдання коректного переходу від значень умовної деформації $0<\gamma<50 \ldots 60 \%$ до величини істинної логарифмічної деформації $0<\varepsilon<1 \ldots 3$. Методика. В роботі проведено теоретичний аналіз виду закономірностей деформаційного зміцнення металів (сплавів) від умовного ступеня деформації, представлено перехід від умовного до логарифмічного (істинного) ступеня деформації металів (сплавів) шляхом аналітичного представлення графіків зміцнення металів у функції ступеня логарифмічної (істинної) деформації на відміну від ступеня відносної (умовної) деформації. Наукова новизна. Представлені аналітичні вирази, які дозволяють використовувати відомі теоретичні дані про деформаційне зміцнення металів (сплавів) за умови невеликих $(50 \ldots 60 \%)$ відносних сумарних деформацій $\gamma$ під час холодної обробки тиском для переходу до логарифмічної істинної деформації $\varepsilon з$ великими сумарними деформаціями. Практична значимість. Отримані математичні вирази дозволяють використовувати накопичені в технічній літературі експериментальні дані про зміцнення металів та сплавів з невеликими відносними (умовними) деформаціями в процесах холодної обробки металів (сплавів) тиском для визначення зміцнення з великими сумарними логарифмічними (істинними) деформаціями. Ці дані також можуть використовуватись для вирішення металознавчих проблем обробки металів тиском, пов'язаних з великими сумарними обтисненнями.

\section{Ключові слова: холодна обробка металів і сплавів тиском; зміцчнення; ступінь деформації}

The strength characteristics of metals and alloys (yield point $\sigma_{02}$, ultimate strength $\sigma_{\mathrm{B}}$, hardness, for example, according to Brinell, HB) during cold deformation, as a rule increase. This information is used both in theoretical calculations and in practical activities in determining of the energy-power parameters of the metal forming processes, the peculiarities of the flow of metals, the formation of product properties, etc.

Most of the known data on the regularities of metal hardening are graphically presented by dependencies of the form 1 in Figure 1.

They are approximated by formulas of the type [1]:

$$
\begin{aligned}
& \sigma_{02}=\sigma_{02_{0}}+a_{T} \gamma^{b_{T}} ; \\
& \sigma_{B}=\sigma_{B_{0}}+a_{B} \gamma^{b_{B}} ; \\
& H B=H B_{0}+a_{H B} \gamma^{b_{H B}},
\end{aligned}
$$

where $\sigma_{02_{0}}, \sigma_{B_{0}}, H B_{0}$ are the initial (before deformation) values of the corresponding characteristics $\left[\mathrm{kgf} / \mathrm{mm}^{2}\right] ; a_{i}, b_{i}-$ empirical values typical for each metal (alloy); $\gamma_{i}-$ total engineering strain:

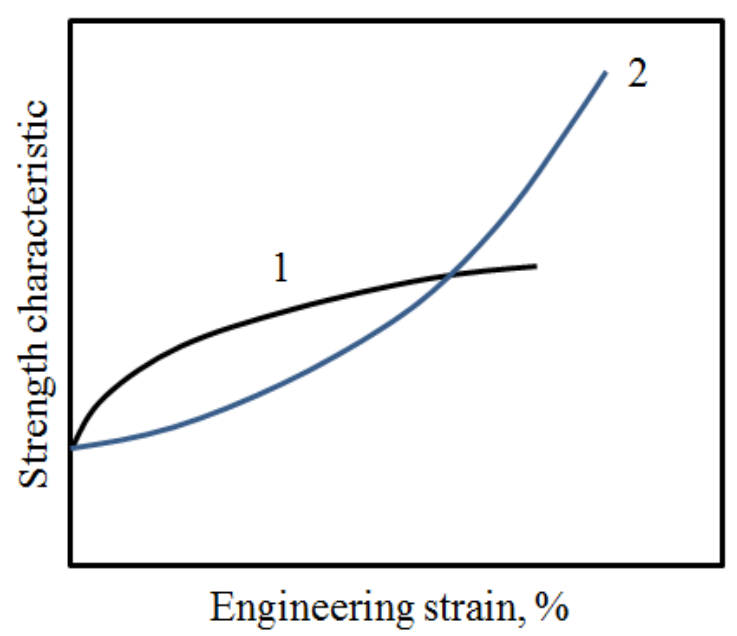

Fig. 1. The Type of Dependence of Strength Parameters on the Engineering Strain: 1 - according to A.V. Tretyakov [1], 2 - according to V.A. Yukhvets [2]

$$
\gamma=\frac{F_{0}-F_{1}}{F_{0}} \times 100=\left(1-\frac{1}{\mu}\right) \times 100 \%,
$$

where $F_{0}$ and $F_{1}$ are the cross-sectional areas of the product before and after deformation; $\mu-$ coefficient of elongation (stretching) for processes with a positive principal deformation (for example, drawing process): $\mu=F_{0} / F_{1}$. 
In this case, the values of $a_{i}$ and $b_{i}$ (where $i$ - is the corresponding strength characteristic) are obtained mainly for $\gamma \leq 50 \ldots 60 \%$.

However, an increase in the total engineering strain to $\gamma=80 \ldots 90 \%$, which is typical, for example, for the processes of drawing and continuous rolling, forms the corresponding dependencies of the type as line 2 in Figure 1 [2]. This is related not so much to physical phenomena occurring in the metal as to the absence of the additively property of $\gamma$ and its nonlinear change while large values.

The previously indicated fact was fixed in [3], but no specific practical recommendations for taking it into account were given.

Physically more reasonable is the dependence of the metals strength properties on the logarithmic (true) strain:

$$
\varepsilon=\ln \frac{F_{0}}{F_{1}}=\ln \mu
$$

This value has the additively property and is linear in the entire range of its variation.

The above may be shown by the following example. Let the initial section of the workpiece $F_{0}=100 \mathrm{~mm}^{2}$. A decrease in the section to $F_{11}=2 \mathrm{~mm}^{2}$ (the first variant of deformation) and to $F_{12}=1 \mathrm{~mm}^{2}$ (the second variant of deformation) is accompanied by the values $\gamma_{1}=98 \%$ and $\gamma_{2}=99 \%$. The absolute value between options $\Delta \gamma=1 \%$. In this case, deformation from $F_{11}$ to $F_{12}$ requires $\gamma_{12}=50 \%$. When using the parameter $\varepsilon$ for the same example, we have: $\varepsilon_{1}=3.91, \varepsilon_{2}=4.61$, $\Delta \varepsilon=0.7$, which is equal to $\varepsilon_{12}$ when deformed from $F_{11}$ to $F_{12}$.

Figure 2 shows a graphical transformation of the dependence $\sigma=\psi(\gamma)$ into $\sigma=\psi_{1}(\varepsilon)$. Here curve 2 can be approximated quite accurately by an equation of the form:

$$
\sigma_{i}=\sigma_{0 i}+A_{i} \cdot \sqrt{\varepsilon}
$$

which corresponds to the Hall-Petch equation [3].

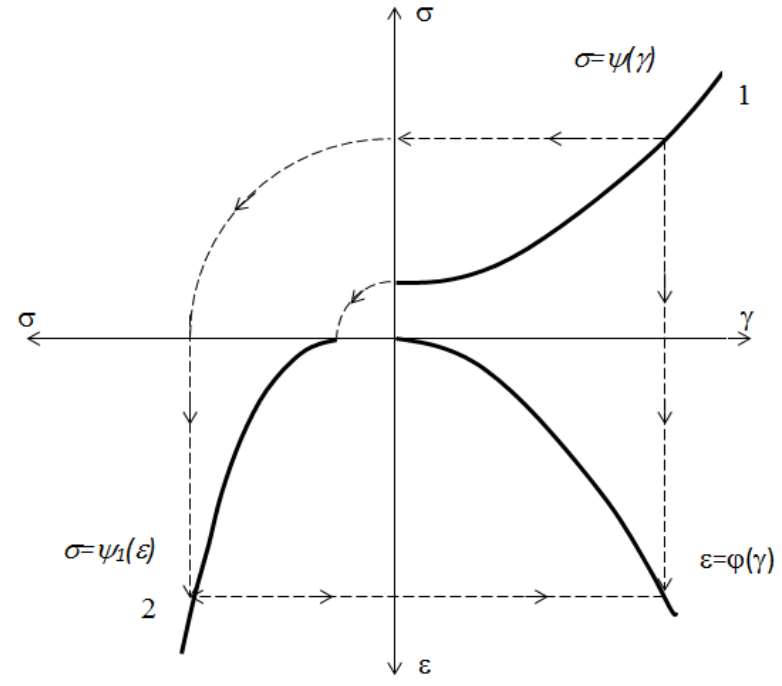

Fig. 2. Transformation from Argument $\gamma$ (curve 1) to $\varepsilon$ (curve 2) in the Graphical Representation of Hardening Curves

The problem is that in the technical literature there are practically no data on the values of the coefficient $A_{i}$ for $\sigma_{02_{0}}, \sigma_{B_{0}}, H B_{0}$. Also, there is visibly not enough information about the regulaties for metals hardening in the area of large deformations. The latter can be largely compensated by extrapolating the monotonically varying dependence 2 in Figure 2 into the area of large values of $\varepsilon$.

On the basis of the foregoing, the purpose of the work is the correct transformation from the engineering strain $0<\gamma<50 \ldots 60 \%$ to the true logarithmic strain $0<\varepsilon<1 \ldots 3$.

The equality of the values of any of the strength parameters determined by the formulas of types (1) and (6) gives the value of $A_{i}$ only for one specific degree of deformation.

To adequately replace $\gamma$ in (1) by $\varepsilon$ in (6), it is necessary to average the corresponding dependences in the range of variation of the degrees of deformation $\gamma$ and $\varepsilon$. Taking into account that according to (4) and (5):

$$
\gamma=100 \cdot(1-\exp (-\varepsilon))
$$

and also (1) and (6) we obtain:

$$
\begin{gathered}
\int_{0}^{\varepsilon_{\max }}\left(\sigma_{0}+A_{i} \cdot \varepsilon^{0.5}\right) d \varepsilon= \\
=9.81 \int_{0}^{\varepsilon_{\max }}\left(\sigma_{0}+a_{i} \cdot\left(100 \cdot\left(1-\exp (-\varepsilon)^{b}\right)\right)\right) d \varepsilon,
\end{gathered}
$$


where

$$
A_{i}=9.81 \cdot a_{i} \cdot 100^{b_{i}} \frac{\int_{0}^{\varepsilon_{\max }}(1-\exp (-\varepsilon))^{b_{i}} d \varepsilon}{\int_{0}^{\varepsilon_{\max }} \varepsilon^{0.5} d \varepsilon},
$$

or

$$
A_{i}=9.81 \cdot a_{i} \cdot I
$$

where

$$
I=100^{b_{i}} \frac{\int_{0}^{\varepsilon_{\max }}(1-\exp (-\varepsilon))^{b_{i}} d \varepsilon}{\int_{0}^{\varepsilon_{\max }} \varepsilon^{0.5} d \varepsilon} .
$$

The coefficient 9.81 assumes a transition from the dimension $\mathrm{kgf} / \mathrm{mm}^{2}[1]$ to $\mathrm{MPa}, \varepsilon_{\max }$ is the maximum value of the logarithmic true strain corresponding to $\gamma_{\max }$ in the range $0<\gamma<\gamma_{\max }$ according to [1].

It is difficult to obtain the exact value of $I$ from (11). As a result of numerical integration and approximation, an expression is obtained:

$$
I=1.5 \cdot \exp \left(x_{1} b^{4}+x_{2} b^{3}+x_{3} b^{2}+x_{4} b\right),
$$

where:

- for $\gamma=63.2 \%$ (that is $\varepsilon=1$ ):

$x_{1}=0.0455, x_{2}=-0.2015, x_{3}=0.4027$, $x_{4}=3.3588$;

- for $\gamma=86.5 \%$ (that is $\varepsilon=2$ ):

$x_{1}=0.4981, x_{2}=-2.1399, x_{3}=3.2508$, $x_{4}=2.094$.

To assess the data obtained, a special analysis was performed. In this case, the results of an experimental (index "E") study of the hardening of a number of steels in accordance with the formula of the form (6) when wire rod drawing with an average initial diameter of $6.5 \mathrm{~mm}$ and a degree of deformation $\varepsilon_{\max }$ up to 3 ( $\gamma$ up to $95 \%$ ) were used. The experiments were carried out in the conditions of several hardware Ukrainian enterprises. The chemical composition of investigated steels and corresponding hardening parameters are presented in Tables 1 and 2 .

The obtained values of $\mathrm{A}_{\mathrm{BE}}$ and $\mathrm{A}_{02 \mathrm{E}}$ were compared with the calculated (index " $\mathrm{C}$ ") values $A_{B C}$ and $A_{02 C}$, obtained according to formulas (10) and (12) taking into account the levels $a_{i}$ and $b_{i}$ at $\gamma_{\max } \approx 62 \%\left(\varepsilon_{\max } \approx 1\right)$ from the monograph [1] for steels closest to those studied. In this case, it was assumed that the initial levels of ultimate strength $\sigma_{\mathrm{B} 0}$ and yield strength $\sigma_{02_{0}}$ were adequate.

Comparison of the calculated and experimental coefficients $A_{B}$ and $A_{02}$, made in the table, indicates a satisfactory coincidence of the corresponding characteristics of hardening and the possibility of extrapolating the data [1] to the range of values $\varepsilon>2 \ldots 3$.

Conclusions. The obtained expressions allow to use the experimental data accumulated in the technical literature on the hardening of metals and alloys with small relative compressions in the processes of cold working of metals by pressure to determine hardening with large total logarithmic deformations (strains). These data can also be used to solve metallophysical problems of metal forming associated with large total deformations. 
Chemical Compositions of Investigated Steels

\begin{tabular}{|c|c|c|c|c|c|c|c|c|}
\hline \multirow{2}{*}{$\begin{array}{c}\text { Steel } \\
\text { Grade }\end{array}$} & \multicolumn{9}{|c|}{ Chemical composition in \% } \\
\cline { 2 - 9 } & $\mathrm{C}$ & $\mathrm{Si}$ & $\mathrm{Mn}$ & $\mathrm{Ni}$ & $\mathrm{S}$ & $\mathrm{P}$ & $\mathrm{Cr}$ & $\mathrm{V}$ \\
\hline $\mathrm{St} 0 \mathrm{M}$ & $\leq 0.15$ & - & - & & $\leq 0.06$ & $\leq 0.07$ & & - \\
\hline $\mathrm{St} 0$ & $\leq 0.23$ & - & - & $\leq 0.30$ & $\leq 0.06$ & $\leq 0.07$ & $\leq 0.30$ & - \\
\hline $\mathrm{St} 1 \mathrm{kp}$ & $0.06 \ldots 0.12$ & $\leq 0.05$ & $0.25 \ldots 0.50$ & $\leq 0.30$ & $\leq 0.05$ & $\leq 0.04$ & $\leq 0.30$ & - \\
\hline $\mathrm{St} 1$ & $0.06 \ldots 0.12$ & $0.15 \ldots 0.30$ & $0.25 \ldots 0.50$ & $\leq 0.30$ & $\leq 0.05$ & $\leq 0.04$ & $\leq 0.30$ & - \\
\hline $\mathrm{St} 2 \mathrm{kp}$ & $0.09 \ldots 0.15$ & $\leq 0.05$ & $0.25 \ldots 0.50$ & $\leq 0.30$ & $\leq 0.05$ & $\leq 0.04$ & $\leq 0.30$ & - \\
\hline $\mathrm{St} 2$ & $0.09 \ldots 0.15$ & $0.15 \ldots 0.30$ & $0.25 \ldots 0.50$ & $\leq 0.30$ & $\leq 0.05$ & $\leq 0.04$ & $\leq 0.30$ & - \\
\hline $10 \mathrm{kp}$ & $0.07 \ldots 0.14$ & $\leq 0.07$ & $0.25 \ldots 0.50$ & $\leq 0.30$ & $\leq 0.04$ & $\leq 0.035$ & $\leq 0.15$ & - \\
\hline 10 & $0.07 \ldots 0.14$ & $0.17 \ldots 0.37$ & $0.35 \ldots 0.65$ & $\leq 0.30$ & $\leq 0.04$ & $\leq 0.035$ & $\leq 0.15$ & - \\
\hline $20 \mathrm{kp}$ & $0.17 \ldots 0.24$ & $\leq 0.07$ & $0.25 \ldots 0.50$ & $\leq 0.30$ & $\leq 0.04$ & $\leq 0.035$ & $\leq 0.25$ & - \\
\hline 20 & $0.17 \ldots 0.24$ & $0.17 \ldots 0.37$ & $0.35 \ldots 0.65$ & $\leq 0.30$ & $\leq 0.04$ & $\leq 0.035$ & $\leq 0.25$ & - \\
\hline $\mathrm{sv}-08 \mathrm{~A}$ & $\leq 0.10$ & $\leq 0.03$ & $0.35 \ldots 0.60$ & $\leq 0.25$ & $\leq 0.03$ & $\leq 0.03$ & $\leq 0.12$ & - \\
\hline $08 \mathrm{kp}$ & $0.05 \ldots 0.12$ & $\leq 0.03$ & $0.25 \ldots 0.50$ & $\leq 0.30$ & $\leq 0.04$ & $\leq 0.035$ & $\leq 0.10$ & - \\
\hline SV- & $0.05 \ldots 0.11$ & $0.70 \ldots 0.95$ & $1.80 \ldots 2.10$ & $\leq 0.25$ & $\leq 0.025$ & $\leq 0.03$ & $\leq 0.2$ & - \\
$08 \mathrm{G} 2 \mathrm{~S}$ & & & & & \\
\hline $09 \mathrm{G} 2$ & $\leq 0.12$ & $0.17 \ldots 0.37$ & $1.4 \ldots 1.8$ & $\leq 0.30$ & $\leq 0.035$ & $\leq 0.03$ & $\leq 0.30$ & $\leq 0.12$ \\
\hline
\end{tabular}

Table 2

Comparison of Experimental and Calculated Characteristics of Hardening of Some Steels

\begin{tabular}{|c|c|c|c|c|c|c|c|c|c|c|c|}
\hline \multicolumn{4}{|c|}{ Experiment } & \multicolumn{6}{c|}{ Calculation by formulas (10) and (12) } \\
\hline Steel & $\begin{array}{c}\sigma_{\mathrm{B} 0}, \\
\mathrm{MPa}\end{array}$ & $\begin{array}{c}\mathrm{A}_{\mathrm{BE}}, \\
\mathrm{MPa}\end{array}$ & $\begin{array}{c}\sigma_{02_{0}}, \\
\mathrm{MPa}\end{array}$ & $\begin{array}{c}\mathrm{A}_{02 \mathrm{E}}, \\
\mathrm{MPa}\end{array}$ & Steel & $\begin{array}{c}a_{\mathrm{B}}, \\
\mathrm{kgf} / \mathrm{mm}^{2}\end{array}$ & $b_{\mathrm{B}}$ & $\begin{array}{c}\mathrm{A}_{\mathrm{BC}}, \\
\mathrm{MPa}\end{array}$ & $\begin{array}{c}a_{02}, \\
\mathrm{kgf} / \mathrm{mm}^{2}\end{array}$ & $b_{02}$ & $\begin{array}{c}\mathrm{A}_{02 \mathrm{C}}, \\
\mathrm{MPa}\end{array}$ \\
\hline St0M & 384 & 334 & 261 & 412 & $\mathrm{St} 0$ & 1.65 & 0.68 & 272 & 5.62 & 0.46 & 415 \\
\hline St1kp & 378 & 273 & 216 & 383 & $\mathrm{St} 1$ & 2.68 & 0.57 & 295 & - & - & - \\
\hline St2kp & 382 & 306 & 222 & 413 & $\mathrm{St} 2$ & 1.86 & 0.71 & 342 & 3.06 & 0.62 & 404 \\
\hline $10 \mathrm{kp}$ & 406 & 338 & 255 & 415 & 10 & 2.78 & 0.62 & 367 & 2.95 & 0.64 & 420 \\
\hline 20kp & 490 & 310 & 290 & 386 & 20 & 0.58 & 0.98 & 291 & 3.16 & 0.64 & 449 \\
\hline sv-08A & 363 & 320 & 208 & 419 & $08 \mathrm{kp}$ & 1.48 & 0.75 & 315 & 7.00 & 0.60 & 425 \\
\hline SV- & 610 & 305 & 388 & 451 & $09 \mathrm{G} 2$ & 0.64 & 0.91 & 274 & 3.46 & 0.46 & 435 \\
08G2S & & & & & & & & & & & \\
\hline
\end{tabular}

\section{REFERENCES}

1. Tret yakov A.V. and Zyuzin V.I. Mekhanicheskie Svoystva Metallov i Splavov pri Obrabotke Davleniyem [Mechanical properties of metals and alloys during metal forming]. Moscow : Metallurgiya Publ., 1973,224 p. (in Russian)

2. Yukhvets Y.A. Volochylnoe Proyzvodstvo [Drawing production]. Part 1. Moscow : Metallurhyzdat Publ., 1995, 272 p. (in Russian)

3. Zolotarevskiy V.S. Mekhanicheskie Svojstva Metallov : uchebnik dlya vuzov [Mechanical properties of metals : textbook for universities]. 2nd ed. Moscow : Metallurgiya Publ., 1983, 352 p. (in Russian)

\section{СПИСОК ВИКОРИСТАНИХ ДЖЕРЕЛ}

1. Третьяков А. В., Зюзин В. И. Механические свойства металлов и сплавов при обработке давлением. Москва : Металлургия, 1973. 224 с.

2. Юхвец И. А. Волочильное производство. Ч. 1. Москва : Металлургиздат, 1995. 272 с.

3. Золотаревский В. С. Механические свойства металлов : учеб. для вузов. 2-е изд. Москва : Металлургия, 1983. 352 c.

Надійшла до редакції: 12.03.2021. 